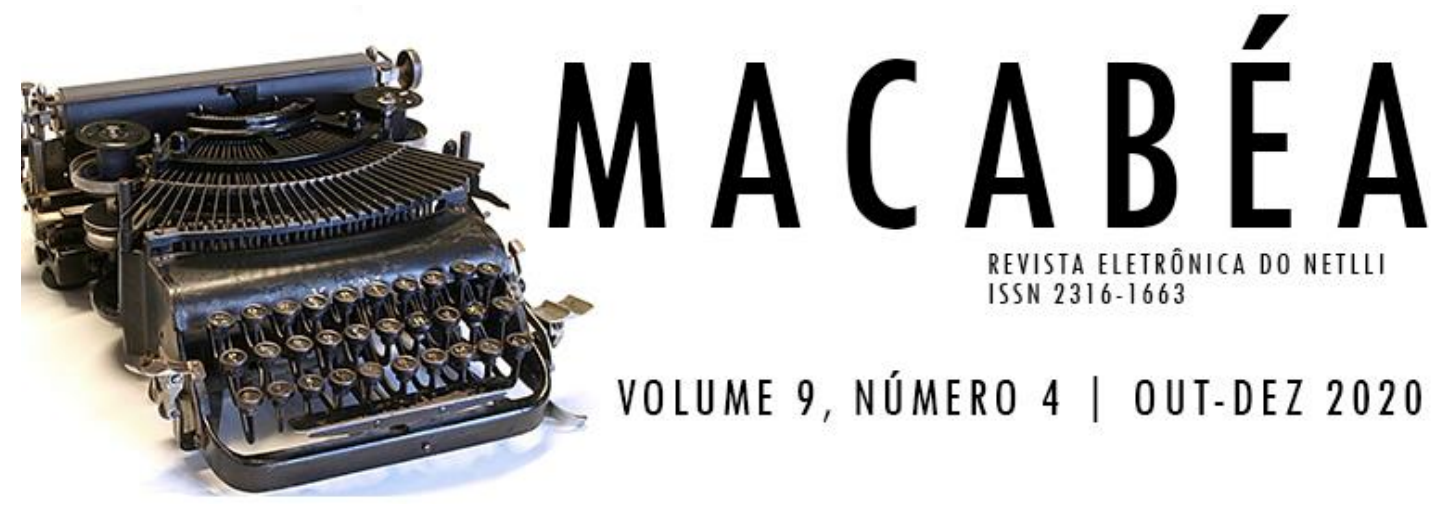

\title{
OS ROMANCES DE SABBAS DA COSTA NOS JORNAIS OITOCENTISTAS
}

\section{THE ROMANCES OF SABBAS DA COSTA IN EIGHTEENTH CENTURY NEWSPAPERS}

ANTONIA PEREIRA DE SOUZA PONTIFÍCIA UNIVERSIDADE CATÓLICA DO RIO GRANDE DO SUL, BRASIL

\author{
RESUMO | INDEXAÇÃO | TEXTO | REFERÊNCIAS | CITAR ESTE ARTIGO | A AUTORA \\ RECEBIDO EM 17/07/2020 • APROVADO EM 12/09/2020
}

\begin{abstract}
The purpose of this article is to analyze the circulation of the novels $O$ Cãozinho and Jacy, by Sabbas da Costa, in the newspapers A situation (1865) and Semanário Maranhense (1867/1868), in São Luís - Maranhão, as well as to describe some themes in these works and tell the story of these supports. The research was carried out in a primary source, since newspapers were used; as well as bibliographic, since books were also searched, such as Botelho (2010), Sacramento Blake (1883) and Fausto (1995, involving qualitative and critical-analytical procedures.
\end{abstract}

\section{Resumo}

0 objetivo deste artigo é analisar a circulação dos romances $O$ Cãozinhoe Jacy, de Sabbas da Costa, nos jornais A situação(1865) e Semanário Maranhense (1867/1868), de São Luís - Maranhão, bem como descrever algumas temáticas presentes nessas obras e contar a história desses suportes. A pesquisa foi realizada em fonte primária, visto que foram utilizados jornais; bem como bibliográfica, uma vez que também foram pesquisados livros, a exemplo de Botelho (2010), Sacramento Blake (1883) e Fausto (1995), envolvendo os procedimentos qualitativos e crítico-analítico. 


\section{Entradas para indexação}

KEYWORDS: Brazilian Literature; Maranhense Literature;Sabbas da Costa; Circulation Romances in the newspapers. Newspaper history.

PALAVRAS-CHAVE: Literatura Brasileira; Literatura Maranhense; Sabbas da Costa; Circulação Romances nos jornais. História dos jornais.

\section{Texto integral}

\section{INTRODUÇÃO}

Conforme Sacramento Blake (1893, p. 451-452), Francisco Gaudêncio Sabbas da Costa nasceu no Maranhão (São Luís), em "5 de dezembro de 1829 e faleceu em outubro de 1874". Filho de João Gualberto da Costa e de Raymunda Lamagner Frazão da Costa. Escreveu muitas peças teatrais, como: Francisco II, ou a liberdade da Itália (1861); Garibaldi ou o seu primeiro amor (1862); Pedro V, ou o moço velho; 1862; 0 Barão de Oyapok (1863); A buena-dicha (1862); e o romance Um amor fatal (1868). Não se referiu aos romances publicados nos jornais.

Neste artigo pretendemos analisar a circulação dos romances 0 Cãozinho e Jacy, de Sabbas da Costa, nos jornais A situação (1865) e Semanário Maranhense (1867/1868), de São Luís - Maranhão, bem como descrever algumas temáticas presentes nessas obras e contar as histórias desses suportes, posto que as histórias dos jornais é inerente às histórias de suas publicações. A pesquisa foi realizada em fonte primária, visto que foram utilizados jornais; bem como bibliográfica, uma vez que também foram pesquisados livros, a exemplo de Botelho (2010), Sacramento Blake (1883) e Fausto (1995), envolvendo os procedimentos qualitativos e críticoanalítico.

Os romances de Sabbas da Costa pertencem ao Romantismo Brasileiro, em vista disso, apresentam temáticas comuns a outros autores desse período como José de Alencar e Bernardo Guimarães, por exemplo, ao tratar de indianismo, em Jacy e alguns aspectos da escravidão, em 0 Cãozinho.

0 artigo está dividido em três partes. Na primeira, "O romance $\mathbf{O}$ Cãozinho no jornal A Situação", mostraremos o modo de circulação e a temática da obra, bem como a história desse periódico. A segunda parte "Semanário Maranhense: inquietações sobre os caminhos da Literatura Maranhense" discorreremos sobre a história desse jornal e a respeito das inquietações que permeavam o meio literário maranhense naquele período, expostas ali por Joaquim Serra. No terceiro item "A cor local no romance Jacy", analisaremos a representação dos índios, negros e ciganos que permeiam o cenário maranhense do romance sabbasense.

\section{O ROMANCE O CÃOZINHO NO JORNAL A SITUAÇÃO}


A Situação: Jornal Político funcionou entre 18 de junho de 1863 e 3 de setembro de 1870. Era um órgão do Partido Conservador. De periodicidade semanal, impresso na Tipografia da Situação, na Rua Grande, 19, por J. M. Alves Ferrão. Como era da situação, apresentou um comportamento raro, nos periódicos oitocentistas maranhenses: publicava os nomes dos três redatores: Luís Antônio Vieira da Silva, João da Matta Moraes Rego e Heráclito de Alencastro Pereira da Graça, na primeira página, durante um longo período.

Mesmo com a predominância de assuntos políticos, $A$ Situação veiculou prosa de ficção estrangeira no Folhetim convencional. Ali encontramos $A$ roda de fiar, romance de Luís Enault, em seis capítulos, apresentados nos dias 5 e 12 de janeiro de 1865, exemplares 78 e 80; a peça teatral A Escola dos maridos, de Molière, e a novela maranhense 0 Cãozinho, de Sabbas da Costa, sobre a qual falaremos no capítulo quatro desta tese; além da "Carta a um amigo" e da poesia "Um sonho maravilhoso", entre outros escritos.

O periódico A Situação: Jornal Político propalou a novela/romance 0 Cãozinho, de Sabbas da Costa, no formato comum do Folhetim, em quatro colunas, em média duas páginas por edição; entre 19 de janeiro, n. 81 e15 de abril, n. 93 de 1865. Nesta edição, informou-se que a obra continuaria, mas não existe o exemplar 94, no qual a obra provavelmente terminou, portanto esta ficou incompleta.

Figura 1 - Início do romance 0 Cãozinho (A Situação, 19 jan. 1865, n. 81, p. 1)

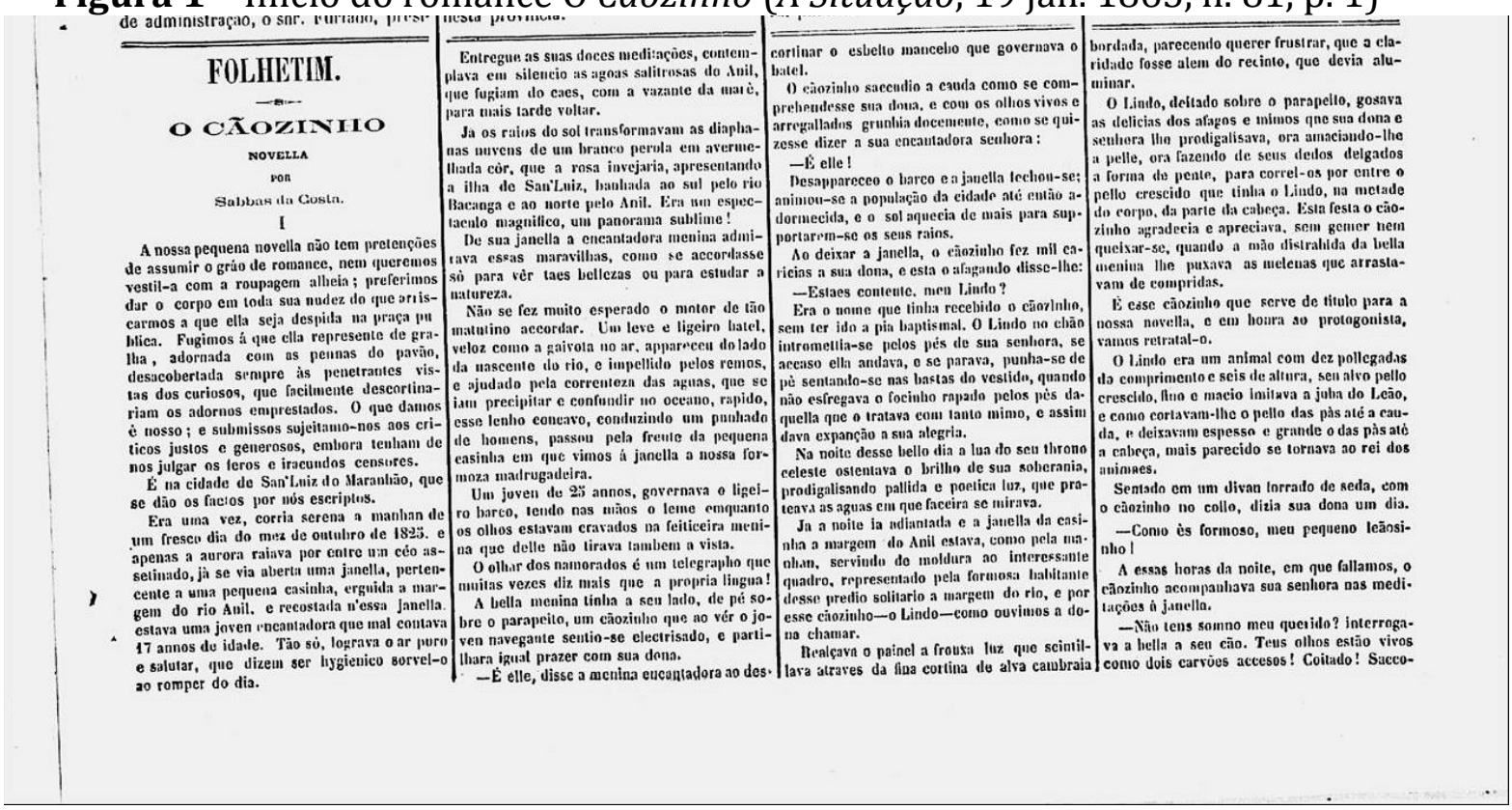

Fonte: http://memoria.bn/.

No último capítulo veiculado, a história encaminhava para o final feliz de Flávio e Matildes, junto com Lindo, o cãozinho mascote do casal. Apesar de Sabbas da Costa prefaciar sua obra informando que não tem pretensões de que ela seja um romance, essa obra poderia ser classificada como tal em vista dos diferentes conflitos que 
apresenta. 0 Cãozinho é uma história de amor, ambientada em São Luís, predominantemente, em 1825. A representação da capital, centra-se na beleza de sua natureza, através de seus rios e do mar, como podemos observar neste trecho:

Já os raios do sol transformavam as diáfanas nuvens de um branco pérola de avermelhada cor, que a rosa invejaria, apresentando a ilha de São Luís, banhada ao sul pelo Rio Bacanga e ao norte pelo Anil. Era um espetáculo magnífico. Um panorama divino (COSTA, A Situação, 19 jan. 1865, n. 81, p.1).

Em torno dessa história de amor, entretanto, Sabbas da Costa discutiu sobre o tráfico de escravos, em um período em que a função de traficante era muito perigosa, porque havia sido proibida pela Inglaterra (1815-1851). 0 protagonista Flávio era comandante de um navio negreiro e Medeiros, o outro pretendente de Matildes, exercia a função de negociante de escravos do mesmo navio. A obra apresenta um diálogo entre o traficante e um dos escravos traficados, no qual a ideia antiescravagista manifesta-se:

Flávio era comandante de navio mercante, que navegava em mares arriscados da Costa da África comerciando [mutilado], que embora perigoso tinha a recompensa de ser lucrativo.

Viera do Rio de Janeiro empregado em negócio de escravo e ninguém o conhecia em Maranhão, segundo ele pensava, apesar de ter nascido aí e deixado sua terra natal de oito para nove anos" (COSTA, A Situação 26 jan. 1865, n. 82).

[...]

- Meu senhor, Flávio, não me conhece?

— Eu? Disse Flávio. Não me recordo de ti.

- É que meu senhor tem trazido tantos de minha terra que já não se lembra de Felipe, aquele que tratava do cãozinho... É verdade. Que fim levou o Lindo? Eu não o vejo desde que meu senhor Monteiro comprou-me a meu senhor Flávio.

Flávio só então fez reparo em Felipe e o reconheceu.

— Estás crescido. És feliz?

- Como pode ser feliz quem é escravo? (COSTA, A Situação 16 fev. 1865, n. 85).

No próximo item veremos a história do Semanário Maranhense, como também um pouco da angústia que pairava sobre a literatura Maranhense, na segunda metade do século XIX, tanto em relação ao suporte jornal quanto ao livro. Expressas no periódico por Joaquim Serra, a ponto de supor que o jornal poderia parar de circular por falta de matérias. 


\section{SEMANÁRIO MARANHENSE: INQUIETAÇÕES SOBRE OS CAMINHOS DA LITERATURA MARANHENSE}

O Semanário Maranhense começou a circular em 1ํㅡ de setembro de 1867, veiculando até 8 de setembro de 1868, com 54 edições, formadas por 8 páginas cada. 0 editor era Belarmino de Mattos. Era impresso por Manoel F. Pires, na Tipografia de Belarmino de Mattos, na Rua da Paz, 7. Em seu Prospecto consta que pretendiam deixar "um arquivo, onde se encontrem vestígios dos esforços empregados por alguns filhos desta terra, em bem da literatura e das artes" (Semanário Maranhense, 1 set. 1867, n. 1, p.1). Os redatores afirmaram ainda que faltavam jornais que versassem sobre a Literatura no Maranhão e esse jornal preencheria essa lacuna, tomando por normas os periódicos maranhenses, de São Luís: Jornal de Instrução e Recreio (1845-1846), O Arquivo (1846), Revista Universal Maranhense (1846-1850). Para esses redatores, o jornal equiparava-se ao livro, sendo aquele mais popular que este: "O jornal, que é a forma mais popular do livro, deve ser a arena onde venham ensaiar as forças todos aqueles, que estão dispostos a trabalhar" (Semanário Maranhense, 1 set. 1867, n. 1, p.1).

Parte da crítica declara que o romance maranhense teve início com esse jornal; outra parte, considera o nascimento do romance maranhense mais tardiamente, entre 1870 e 1881. Nossa pesquisa em jornais, retroagiu o começo do romance do Maranhão para 1845, com o romance Eponina, de Augusto Frederico Colin, publicado no jornal $O$ Arquivo, além disso apresenta muitos outros romances publicados antes de 1868.

Esse jornal foi mais uma tentativa de imprensa literária em São Luís, no modelo do Jornal de Instrução e Recreio, O Arquivo e da Revista Universal Maranhense, mas o resultado também não foi bom, uma vez que seguiu o mesmo destino de parar de circular em um ano, como aconteceu com seus antecessores. 0 resultado dessa última tentativa, dentro do Primeiro Ciclo da Literatura Maranhense, não agradou nem a seu idealizador, uma vez que se referiu ao periódico e a seus antecessores, como produtos que não condiziam com a capacidade intelectual dos jornalistas maranhenses, desta forma:

O Semanário Maranhense não passou de tentativa malograda, e alguns pequenos jornais de literatura fugitiva, fundados por estudantes do Liceu, de escassa circulação e existência fugaz, por forma alguma representam a grande vitalidade intelectual e a superioridade de estudos literários dos jornalistas maranhenses (SERRA, 2001, p. 62).

Joaquim Serra foi muito rígido, ao falar sobre esse jornal, porque, mesmo circulando por um curto período, foi constante a presença dos romances de Sabbas da Costa, 
além de poesias de muitos escritores maranhenses, como Sousândrade, que ensaiava seu Guesa Errante.

Esse jornal também não foi apenas literário, posto que divulgava notícias de outras províncias e do exterior e comentava-as, na sessão Crônica Externa, de Reimar; e na Crônica Interna, de Castellamare, veiculava notícias e reflexões a respeito do Maranhão. Isto é, o jornal publicava o mesmo tipo de crônica que os demais, geralmente, veiculavam no Folhetim, mas como $O$ Semanário não apresentava esse espaço, as crônicas jornalísticas, bem como todos os que foram publicados nesse periódico ocupavam o corpo do jornal.

Na Crônica Interna de 1ํㅜ de setembro, de Castellamare (Joaquim Serra), o cronista mostrou-se impaciente com a falta de acontecimentos para noticiar, além disso estava incomodado com a escassez de produção literária que pairava sobre a província, questionou sobre o que faziam os escritores que não escreviam, e se o faziam não organizavam seus escritos, viviam perdidos, com exceção de alguns poetas, como Sousândrade, além do escritor Gentil Braga. Apelou para que se escrevesse mais, independente das adversidades da vida, além de ressaltar o valor da Literatura "o belo" que aparentemente utópica em um tempo "amanhã será uma realidade muito reverenciada". Dessa forma, o cronista instigava os compatriotas para o exercício da Literatura, em vista de não acreditar que eles haviam deserdado. Precisavam realmente se organizar em relação a essas publicações, porque, em sua maioria, ficavam soltas pelos jornais, como escritos independentes, descontínuos:

[...] onde estão tantas obras, que o público espera impaciente; e o que fazem tantos escritores festejados e bem queridos em nosso mundo literário?

Uns dormem o sono da morte, e as suas obras jazem esparsas, mau grado a ansiedade pública; outros descansam mergulhados em um ócio repreensível, quando competia-lhes apresentar os frutos que foram profetizados por lindíssimas flores.

Poucos, bem poucos trabalham, e esses mesmos tomados de um desânimo latente, e como que envergonhados das horas, que dedicam aos estudos literários.

Trajano Galvão e Franco de Sá não têm ainda as suas obras colecionadas; Dias Carneiro, Marques Rodrigues e Nuno Álvares vivem calados e perdidos na multidão.

Entre os poucos que ainda trabalham, conta-se Sousândrade a preparar os últimos cantos do seu imaginoso Guesa Errante, e Gentil Braga que completa a tradução de Eloá [poesia de Vigny] e a sua delicadíssima Clara Verbena (CASTELAMARE (Joaquim Serra), Semanário Maranhense, 1ํ set. 1867, n. 20, p. 8).

A crônica de Castellamare expôs o que acontecia, principalmente, em relação à prosa de ficção, em todo o Primeiro Ciclo da Literatura Maranhense. Situação causada 
provavelmente em vista da obsessão pela poesia que observamos nos jornais de Caxias e São Luís; além de uma possível falta de domínio dos gêneros em prosa, porque ainda estavam em construção. Dificuldade expressa inclusive pelos escritores. Muitos dos autores que se dispuseram a escrever prosa de ficção produziram escritos curtos, ou publicaram apenas trechos; além disso, alguns se mantiveram anônimos. Houve casos em que os escritores publicaram obras completas, mas elas foram destruídas pelo tempo, uma vez que faltam muitos exemplares de jornais que continham capítulos dessas obras. Todas essas tentativas são relevantes para a História da Literatura Maranhense, visto que trazem à luz os primórdios do romance do Maranhão; precisam, portanto ser valorizadas juntamente com os romances que ainda reinam completos nas páginas dos periódicos oitocentistas desse estado.

O medo de não ter o que publicar saiu da crônica de Joaquim Serra e continuou numa declaração do editor, na qual sugeria que fossem enviados para aquele jornal artigos a respeito de Literatura, artes e indústria, a fim de serem publicados gratuitamente. Para animar a criatividade ou alertar os prováveis colaboradores, o editor informou ainda que havia pedido escritos para:

Marques Rodrigues, Gentil Braga, Antônio Henriques, Temístocles Aranha, Antônio Rego, Heráclito Graça, Ricardo E. Ferreira de Carvalho, Sousândrade, Sabbas da Costa, Nuno Álvares e Carvalho Filgueiras, tem esperança de obter bons escritos desses Senhores, todos vantajoamente conhecidos nessa província e fora dela. O Editor (Semanário Maranhense, $1^{\circ}$ set. 1867 , p. 8).

O jornal manteve-se ativo por um ano. Deixou de circular, por falta de recursos, não por falta de matérias, uma vez que recebeu muitas colaborações, em atendimento ao apelo inicial do editor. 0 problema financeiro desse jornal pode ser em vista de manter-se apenas com as assinaturas; não publicava anúncios, além disso, era formado por oito páginas, enquanto que os outros jornais desse período tinham quatro páginas, sendo que em duas regularmente publicavam somente anúncios.

Como o periódico estava publicando o romance Os Amigos, de Sabbas da Costa, quando pararia de veicular, o editor permitiu que veiculassem dois exemplares extras, sem custo aos assinantes, a fim de concluir a obra. Essas informações constam na declaração de despedida, agradecimento e promessa do editor, que começa da seguinte forma:

\section{Declaração}

Com o número de hoje concluem o Semanário Maranhense o seu quarto trimestre e despede-se dos assinantes por não poder o editor sustentar por mais tempo a sua publicação. 0 editor confessa-se agradecido a todos os Senhores redatores do Semanário, que tão pontual e gratuitamente o auxiliaram 
nesta empresa e promete dar ainda aos Senhores assinantes, sem retribuição alguma, dois números do jornal, contendo a continuação e conclusão do interessante romance do Sr. Sabbas da Costa, denominado Os amigos [...] (Semanário Maranhense, 23 ago. 1868, n. 52, p. 8).

A seguir, veremos a análise de Jacy, obra em que Sabbas da Costa promete ater-se somente ao cenário maranhense, como um grande passeio por São Luís e cidades como Coroatá, Codó, Caxias, Rosário, São Bento, representando questões a respeito de diferentes tipos de habitantes desse estado, como: índios, negros, brancos e ciganos.

\section{A COR LOCAL NO ROMANCE JACY}

No Semanário Maranhense, circularam os romances de Sabbas da Costa: Jacy (lenda/romance maranhense), com 14 capítulos, no período de $1^{\circ}$ de setembro a 19 de dezembro de 1867; Jovita, composto por 6 capítulos, de 12 de janeiro a 2 de fevereiro de 1868; Os amigos (romance maranhense), com 25 capítulos, de 8 de março a 8 de setembro de 1868. Os títulos dessas obras são bastante divulgados, porém não encontramos registros de que tenham sido lidas, por exemplo, artigos, dissertações ou teses, nos quais tenham sido corpus. Parece que, como essas obras continuaram somente no jornal, não despertaram muito o desejo de leitura atualmente. Ficaram apenas com a indicação da crítica mais atual, de que representariam o início do cânone literário maranhense, em prosa de ficção; sobretudo Jacy, eleito pela crítica como o primeiro romance do Maranhão, porque iniciou a série de obras que Sabbas da Costa difundiu no Semanário Maranhense. Em vista disso, escolhemos o romance Jacy para verificarmos o que o autor representou nessa obra.

No exórdio dessa obra, o autor comprometeu-se a apresentar um escrito de cor inteiramente maranhense, não envolveria o estrangeiro, nem as outras províncias brasileiras. Dirigiu-se especialmente às leitoras:

As cenas que vamos descrever neste pequeno esboço de romance, servem para apresentar as nossas amáveis leitoras um pouco do que é brasileiro, e especialmente maranhense; daquilo que possuímos com abundância, sem nos ser necessário o que é estrangeiro e não tem a cor nacional; inteiramente local (COSTA, Semanário Maranhense, $1^{0}$ set. 1867, p. 3).

0 romance Jacy discorre sobre índios, ciganos, negros e brancos, que ocupavam o espaço maranhense, na década de 1840, entre Coroatá, Codó, Caxias, Rosário, São 
Bento e São Luís; com seus costumes, fragilidades e defeitos, que desencadeavam conflitos; fugindo do estereótipo de heróis, vítimas ou algozes. Cada grupo lutava para resolver as questões que os incomodavam, de acordo com o que parecesse adequado naquele contexto; embora muitas vezes não fossem decisões sensatas.

Figura 2 - Início do romance Jacy (Semanário Maranhense, 1ํo set. 1867, n. 1, p. 3)

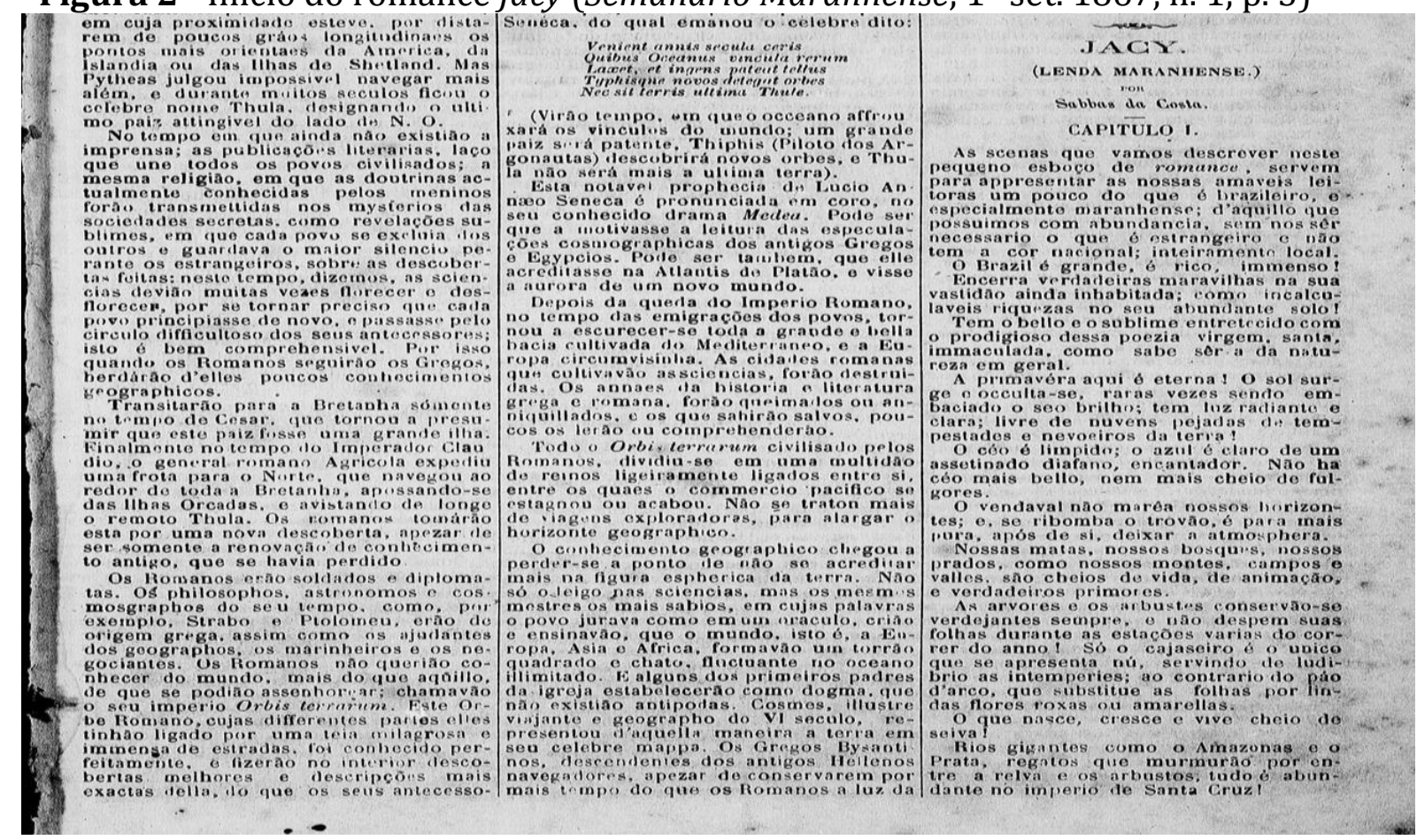

Fonte: http://memoria.bn.br/.

Os índios descritos no romance eram os tapuias, inimigos dos gamelas, timbiras e guajajaras. Foram representados com seus costumes (moradias, crenças, danças, bebidas); mas não era o índio apenas coletor de seu sustento na natureza, como a História o apresenta muitas vezes, pois sobrevivia mais a custas de assaltos que praticavam constantemente às fazendas de produtores de algodão, milho e feijão e criadores de pequenos animais; às vezes, sendo feridos ou mortos em confronto com escravos defensores desses latifúndios, como observamos nesta fala do cacique Ibakeocu:

- Meus filhos, grande desgraça Tupã nos atirou para esmagar nossas glórias ganhas a inimigos. Os bravos que deviam nos trazer o que necessário é a nossa taba, dando correrias nas fazendas vizinhas foram desbaratados, foram mortos! (COSTA, Semanário Maranhense, 6 out. 1867, n. 6, p. 4). 
Quando Augusto Monteiro, um dos fazendeiros, foi eleito governador da província, Hermenegildo, outro fazendeiro, que era assaltado, em média, duas vezes por semana pelos índios, foi à capital em busca de uma providência. A solução encontrada foi uma tentativa de catequizá-los. Levaram-nos para São Luís, com a ajuda de Bento José, filho de africano com tapuia. Apenas dois indígenas viram essa ação como escravidão e resistiram: Madu, que preferiu morrer; e Seemira, mãe de Abaguaçu, que se recusou a ir com os expedicionários, mas faleceu no incêndio da aldeia, provocado pelos soldados da expedição.

Na capital, muitos índios morreram em pouco tempo, acometidos por doenças ou pela falta de adaptação; além disso, sofreram violência cultural, como serem batizados, com exceção dos protagonistas Jacy e Abaguaçu. 0 cacique Abaguaçu ao ver a filha Tatyara morta, deu cabo da própria vida. Jacy voltou para a destruída tribo Tupi, levando as cinzas do marido e da filha. Mas ela também faleceu, exausta da viagem e de tristeza. Quando a província trocou de governador, muitos desses índios foram recrutados para a Armada do Estado e enviados para o Rio de Janeiro. A obra é, portanto, também uma crítica às soluções encontradas pelo branco na tentativa de adaptar o índio aos costumes europeus: "Ainda não havia dois meses, que os matreiros estavam na cidade, já tinham falecido mais de cem atacados de epidemia devido a mudança de comidas, de usos e costumes" (COSTA, Semanário Maranhense, $1^{\circ}$ dez. 1867, p. 3 ).

Conforme Botelho (2010), tribos inteiras de índios eram levadas para perto de cidades e vilas, como uma forma de escravizá-las com o consentimento do "estado português e da igreja”. A partir de 1757, com a revogação do Alvará do Marquês de Pombal, que libertava os indígenas da escravidão, desde 1857, os índios que atacavam fazendas e povoados podiam ser escravizados, em vista de serem considerados bárbaros e perigosos. Acabaram sendo "exterminados pela guerra, pela escravidão ou pela discriminação" (BOTELHO, 2010, p. 16).

Os ciganos também buscavam seu sustento surrupiando as fazendas, no entanto em vez de travarem brigas, usavam a sedução de Esperanza, que entabulava conversas, supostamente propondo algum negócio a fazendeiros e feitores, enquanto os demais pegavam o que podiam, desarmavam o acampamento e continuavam a viagem: [Os ciganos seguiram viagem] de alforjes recheados de carne de porco, galinhas, patos e de muitas outras aves apanhadas e mortas às ocultas" (COSTA, Semanário Maranhense, 15 set. 1867, p. 3). A sedutora também não teve um final feliz, pois José Gaspar, o feitor da fazenda Santo Ângelo, encantado com a jovem, uniu-se aos ciganos até que ela engravidasse, mas fugiu no dia do casamento, que seria realizado em Caxias. Esperanza ficou louca e faleceu sem ter forças para ter o filho. Calisto, irmão da jovem, ao reencontrar Gaspar, matou-o.

Os escravos foram representados de várias formas, com destaque pela violência como combatiam os índios, uma vez que feriam, mutilavam e matavam os tupis, em nome da proteção dos negros e das fazendas para as quais trabalhavam, como Jacinto, filho do capataz da fazenda Santo Ângelo. Sem embargo, quando os negros eram foragidos e formavam quilombos, estes tornavam-se invasores de fazendas e seriam combatidos pelo governo. Parte do combate entre negros e índios foi apresentada desta forma: 
Os índios surpreendidos e vendo caírem mortos e feridos os companheiros valentes, redobravam de ardor e sequiosos de vingança, arremessavam-se contra Jacinto e os seus iguais, impelidos talvez pelo destino.

Negros e gentios confundidos, transtornados, tintos de sangue, calçando aos pés mortos e moribundos, davam berros tremendos que repercutiam pelo espaço, como trovões no céu! Eram selvagens batendo-se com selvagens, que melhor diríamos: eram feras exterminando feras.

Foi uma carnificina horrenda! Nem as mulheres escaparam a matança! (COSTA, Semanário Maranhense, 29 set. 1867, n. 5, p. 3).

$\mathrm{Na}$ maioria dos romances originais que lemos nesta pesquisa, apesar do tom antiescravagista presente; o escravo foi representado como um ser que defendia os valores de seus donos. O romance que descreveu o escravo arquitetador de fugas ou revoltas A Cabana de Pai Tomé, não se manteve nas páginas dos jornais. Tratar do assunto com cautela, pode ser uma estratégia dos escritores para facilitar a chegada dessas obras aos leitores, bem como para viabilizar a aceitação dessas entre parte do público leitor, que, em grande maioria, era proprietário de escravos. Com esse comportamento prudente, os escritores conseguiam aos poucos "regar a semente da abolição", através da circulação de seus escritos.

Na verdade, entre os escravos negros e seus donos, conforme Boris Fausto (1995), existiam muitos conflitos, em vista de, assim como os índios, os negros também se oporem à escravidão, por isso agrediam seus senhores, fugiam, e formavam quilombos, onde se organizavam de forma semelhante à que viviam na África:

Seria errôneo pensar que enquanto os índios se opuseram à escravidão, os negros a aceitavam passivamente. Fugas individuais ou em massa, agressões contra senhores, resistência cotidiana fizeram parte das relações entre senhores e escravos, desde os primeiros tempos. Os quilombos, ou seja, estabelecimentos de negros que escapavam à escravidão e recompunham no Brasil formas de organização social semelhantes às africanas, existiram às centenas no Brasil colonial (FAUSTO, 1995, p. 52).

Outro romance em que também existem ciganos foi propalado no jornal $O$ Eco da Verdade. Desse periódico só existe cópia da edição 10, veiculada em 26 de março de 1860. O exemplar pertencia a Cândido Mendes, pois seu nome está assinado numa das páginas. 0 periódico era impresso na Tipografia do Progresso, por Belarmino de Mattos. Nessa edição, começa, no corpo do jornal, o romance A floresta, ou o roubo, 
assassinato e desfloramento dos ciganos - romance histórico, assinado por Um Maranhense. De acordo com o pequeno prefácio do romance, essa seria a primeira obra de "um jovem esperançoso" (Eco da Verdade, 26 mar. 1860). A temática desse escrito era diferente das habituais daquele período. Narra que um grupo de ciganos chegou, à noite, numa floresta, perto da vila de Anapurus, Maranhão. Eles acomodaram os animais e as crianças e foram dormir. Quando a donzela sonhava que estava sendo atacada e se defendendo; e o chefe da equipe também sonhava que defendia a jovem, o grupo foi atacado por Barriga-Lisa e seus cangaceiros. Não existem mais cópias dos jornais que continuariam a história.

O quadro seguinte resume a circulação dos romances de Sabbas da Costa encontrados em nossa pesquisa, com seus respectivos períodos de circulação e os jornais em que veicularam.

Quadro 1 - Romances de Sabbas da Costa publicados nos jornais

\begin{tabular}{|l|l|l|l|}
\hline Romance & Autor & Período & Jornal \\
\hline O Cãozinho & Sabbas da Costa & $\begin{array}{l}19 \text { jann. -14 abr. } \\
1865\end{array}$ & $\begin{array}{l}\text { A Situação: Jornal } \\
\text { Político(1865) }\end{array}$ \\
\hline Jacy & Sabbas da Costa & $\begin{array}{l}1 \text { set. - 19 dez. } \\
1867\end{array}$ & $\begin{array}{l}\text { Semanário } \\
\text { Maranhense (1867- } \\
1868)\end{array}$ \\
\hline Jovita & Sabbas da Costa & $\begin{array}{l}12 \text { jan. - 2 fev. } \\
1868\end{array}$ & $\begin{array}{l}\text { Semanário } \\
\text { Maranhense (1867- } \\
1868)\end{array}$ \\
\hline $\begin{array}{l}\text { Os amigos } \\
\text { (romance } \\
\text { maranhense) }\end{array}$ & Sabbas da Costa & $\begin{array}{l}8 \text { mar. - 8 set. } \\
1868\end{array}$ & $\begin{array}{l}\text { Semanário } \\
\text { Maranhense (1867- } \\
1868)\end{array}$ \\
\hline
\end{tabular}

Fonte: Arquivo pessoal.

Embora tenha escrito romances e publicado nos jornais maranhenses, Sabbas da Costa ficou mais conhecido, no século XIX, pelas peças teatrais que escreveu, conforme mencionamos na introdução deste artigo, baseada nas considerações de Sacramento Blake, a respeito do escritor maranhense.

No entanto, seus romances, abraçaram temáticas inerentes ao romantismo, como a escravidão e o indígena, descrevendo as formas como viviam, as violências que sofriam e os amores vividos ou desejados.

\section{CONCLUSÃO}

Esta pesquisa lançou luz sobre uma parte da Literatura Maranhense ainda desconhecida ou pouco comentada, no entanto, muito importante para a história da cultura desse estado, uma vez que representa os primórdios do romance maranhense, que teve sua origem nos jornais, ainda em 1845, com o romance Eponina, de de Augusto Frederico Colin, conforme já mencionamos neste artigo, 
embora parte da crítica aponte a obra Jacy, de Sabbas da Costa como iniciadora da prosa de ficção maranhense.

Sabbas da Costa, foi também um crítico da situação literária em que se encontrava o Maranhão na segunda metade do século XIX. Acreditava que se produzia pouca prosa de ficção, creditou a isso o fechamento de muitos jornais literários. Quanto aos poetas, achava que faltava organização nas produções, visto que publicavam avulsamente, sem organizar livros, com exceção de Sousândrade que nesse período estava escrevendo Guesa errante. Faltou mencionar que publicar um livro custava muito caro e isso também desencorajava os autores nesse sentido.

Quanto aos modos de circulação das obras de Sabbas da Costa nos jornais A Situação e Semanário Maranhense, observamos que houve diferença porque no primeiro suporte o romance $\mathbf{O}$ Cãozinho veiculou no rodapé ou Folhetim, forma mais comum das propalações de literatura nos jornais oitocentistas, enquanto que Jacy foi publicada no corpo do Semanário Maranhense. Essa diferença pode ser também em função dos diferentes propósitos dos jornais. Desse modo, A Situação, por declararse político, deixava a literatura em seu lugar comum de manifestação, embora sabendo que ela atraía muitos leitores. Já o Semanário Maranhense, com propósito literário, apresentava a literatura em suas colunas livremente.

Referências e Jornais

BOTELHO, Joan. Conhecendo e debatendo a história do Maranhão. São Luís: Impacto, 2010.

CASTELLAMARE, Pietro de (Joaquim Serra). “Eloá” tradução parafrástica de Flávio Reimar. Semanário Maranhense, 12 jan. 1868, n. 20, p. 2-3. Disponível em: <http://memoria.bn.br/DOCREADER/ docreader.aspx?BIB=720097>. Acesso em: 20 jan. 2015.

COSTA, Sabbas da. Jacy. Semanário Maranhense, São Luís, 1 set./1 dez. 1867. Disponível em:

<http://memoria.bn.br/DOCREADER/docreader.aspx?BIB=720097>. Acesso em 11 jul. 2016.

. 0 Cãozinho. A Situação, São Luís, 19 jan./15 abr. 1865. Disponível em: <http://memoria.bn.br/DOCREADER/DOCREADER.ASPX?BIB=761338>. Acesso em: 2 out. 2016.

SACRAMENTO BLAKE, Augusto Vitorino Alves. Francisco Gaudêncio Sabbas da Costa. In: Dicionário bibliográfico brasileiro. Rio de Janeiro: Tipografia Nacional, 1883, v. 2. p. 451-452. Disponível em: <http://www.bbm.usp.br/>. Acesso em: 12 set. 2013.

FAUSTO, Boris. História do Brasil. 2. ed. São Paulo: EDUSP, 1995. 
A Situação: Jornal Político. São Luís: 1863-1870.

O Eco da Verdade. São Luís: 1860.

Semanário Maranhense. São Luís: 1867-868.

\section{Para citar este artigo}

SOUZA, A. P. de. Os romances de Sabbas da Costa nos jornais de São Luís. Macabéa - Revista Eletrônica do Netlli, Crato, v. 9, n. 4, 2020, p. 483-496.

\section{A Autora}

ANTONIA PEREIRA DE SOUZA é Doutora em Letras, na área de concentração em Literatura e Cultura (2017), pela Universidade Federal da Paraíba. Cursou Mestrado em Letras, na área de Estudos Literários (2010), na Universidade Federal do Piaúí; Especialização em Língua Portuguesa, na Pontifícia Universidade Católica de Minas Gerais (1996) e Licenciatura Plena em Letras: Português e Literaturas de Língua Portuguesa, na Universidade Estadual do Maranhão (1993). 